\title{
Undergraduate Students' Characteristics in Using E-Learning (Schoology) During Outbreak COVID-19
}

\author{
Moh Ali Murad* \\ University of Tadulako \\ alimurad@gmail.com \\ Asriadi \\ University of Tadulako \\ Suryadi Hadi \\ University of Tadulako
}

\author{
Rahmat Mubaraq \\ University of Tadulako \\ Erwan Sastrawan \\ University of Tadulako \\ Femilia Zahra \\ University of Tadulako
}

\begin{abstract}
This study aims to identify the characteristics of undergraduate students using online learning during the COVID-19 pandemic. The methodology in this study uses primary and secondary methods to obtain an in-depth understanding of the problems encountered during online learning. The primary method includes observation, survey, and interview. The secondary method consists of other sources of information obtained by researchers to support this study which include literature review, and other sources. This study identified several issues as the barrier to apply online study during the Covid-19 pandemic. Students who were respondents of this research were mostly living outside the city because of social distancing policy. They had been studying and far from internet access and telephone networks. The stage of this research is in the exploratory stage and requires further research on the relationship between variables that can affect the improvement of the performance of lecturers and students during online learning in this pandemic.
\end{abstract}

Keywords: undergraduate students, outbreak, COVID 19, e-learning

\section{INTRODUCTION}

The initial emergence of patients infected with the COVID-19 virus began in China on December 1 , 2019, and was rumored to spread rapidly from one person to another on December 30, 2019 [1]. When it is compared to the impact of death caused by the COVID-19, it shows a lower percentage than previous viruses such as SARS and MERS [2]. Some countries carry out contingency plans to reduce the impact of spreading the virus with social restrictions. This policy can slow down the level of spread of the virus so that the available treatment facilities can be optimized for use [3]. As a result, school or university facilities were closed from learning activities to prevent the rapid spread of the COVID19 virus. According to Allen and Seaman, online learning strategies have been carried out at the time of the threat of the H1N1 pandemic virus [4].

Lecturers deliver their material to students through an application such as Zoom, and provide other facilities such as Google Class to be used as a medium for lecturers to post assignments and record the results of student work. The policy of prohibiting activities outside and following any instructions given by the government is the most crucial thing for every individual to do during a pandemic virus [5]. What is encouraging is that online learning applications have multiplied during the pandemic as needs have increased and covered the shortcomings of previous applications.

Students in the pandemic period understood the intricacies of the Corona virus and followed government protocols for carrying out social restrictions [6]. However, some students in tertiary institutions are also very much affected by the spread of the Corona virus from both psychological and mental aspects. News that spread widely and quickly eventually caused fear in the community [7]. This fear is also experienced by students in conducting the learning process during a pandemic [8]

The learning process that combines face to face with an online approach is known as a hybrid or blended method. The quality of learning in the classroom can be improved with the help of online methods because learning materials can be sent via the internet [9]. Previous research showed that the success of online learning is influenced by several things including ease in getting materials, other students, instructors, time management, costs that must be incurred by students in carrying out online learning [10]. Students who take part in online 
learning have higher grades than students who study in the class [11]. This study aims to see the extent of students' opinions about the learning process during the COVID-19 pandemic.

This article is structured systematically as follows: the first part of this article describes the background of the research; the second part describes the method, and the third part describes and explains the results of the research; the last part of this article summarizes the results obtained from the study and recommendations for further research.

\section{METHOD}

This study delivered a questionnaire to 250 undergraduate students who are studying at Tadulako University in Palu, Central Sulawesi, Indonesia. The questionnaire was delivered through online but only 205 complete the questionnaire. As the protocol of COVID-19, the questionnaire of this study used Google Form to reach the respondents. The objective of using the questionnaire is to help the interviewer to reach conclusions [12]. A questionnaire is considered as a technique which is used to gather data which express the individual perception of every subject which is interviewed in the meaning that every subject has been asked to answer the questions in a predetermined way. Several questions were asked to respondents related to their experience in using Scholoogy Apps during the outbreak of COVID-19. The respondents in this research were studying operation research, and the lecturer also provided videos and posted on YouTube to engage students' interest. This study applied a descriptive method to process the data gathered through the questionnaire.

\section{RESULTS \& DISCUSSION}

\section{Question 1:}

\section{What are the obstacles to practice e-learning} during the outbreak?

In this question, the researcher used open-ended questions to respondents and managed to gather a number of issues faced by students while conducting online learning during the COVID-19 pandemic. Undergraduate students face a major obstacle, namely the Internet network because most of the students are in villages that are difficult to reach by the internet. Since online learning protocols are implemented to prevent the rapid spread of the virus, many students leave the city and return to their homes. The number of tasks that must be completed by respondents per week is very large, causing many of the respondents who were late to collect the results of quizzes or assignments. Learning applications are also an obstacle for students in conducting online learning processes during COVID-19. The form of assignments in groups becomes an obstacle for students in completing assignments or quizzes given during a pandemic. The telephone credit needed to run the application, require large data so that this can affect the speed of the student in collecting and submitting the given assignment.

Research conducted by Baloran found that the level of awareness of students in responding to the COVID-19 pandemic was quite high, for example, the level of their knowledge of the spread process and how to avoid contracting a virus [6]. Regarding the learning methods provided by lecturers, the result of Baloran study shows that most of the respondents complained about the problem of limited internet connection during a pandemic and increased fear of lack of funds because their parents did not have the income to support the learning process who use the internet [6]. The last researcher also recommends that in the future, it is necessary to prepare good planning in dealing with a pandemic by conducting intensive training for teaching staff and students in using ICT. According to Lederman, improving the quality of online learning must be further improved and not just be a temporary decision to deal with the COVID-19 pandemic [13]. Online learning is not currently aimed at dealing with emergency problems caused by the COVID-19 pandemic but is a strategic step towards normal new conditions. The role of the government in providing subsidies is very important, especially in training teachers or lecturers as well as students or students to deal with pandemics or other emergencies in the future.

\section{Question 2:}

How many times do you apply the Apps during the outbreak?

Based on the results of the distribution of questionnaires conducted in this study, the most popular online learning applications are used by students less than 10 times every day, whether given by lecturers or independent study, namely Canvas, Moodle, and other applications. The Zoom application is also included most frequently by students during the COVID-19 pandemic with more than 127 respondents stating users of this application. For usage levels between 11 and 30 times every day, the Schoology and Google Classroom Applications are favourite applications used by students. The table above also illustrates that a small proportion of students use the Zoom and Google Classroom applications for less than forty times.

\section{Question 3:}

3.1 How about the experience in using Schoology Apps during the outbreak?

After a pandemic control protocol was issued on campus, most students returned to their hometowns. The results of the distribution of the questionnaire showed that students generally stated that access to 
online learning through the Schoology application was still relatively good, and they were still able to access it. Based on a survey conducted by respondents in this study stated that the application of Schoology is quite useful for their learning process during the COVID-19 pandemic.

Table 1. Access and benefit of Schoology App during the COVID-19 outbreak

\begin{tabular}{lcc}
\hline \multicolumn{1}{c}{ Description } & Mean & SD \\
\hline Access Schoology & 3.4634 & 1.1897 \\
Benefits of Schoology & 3.5073 & 0.6687 \\
\hline
\end{tabular}

3.2 How do you think about factors that affect you to use Schoology Apps during the outbreak?

Based on students' opinions about the benefits of using the Schoology application, generally, they agree that this application can help their learning process. Nearly half of respondents said that this application helped them learn during a pandemic and less than half of respondents agreed strongly. If seen from the experience of using the application or the student's ability to use the application, then most of the respondents do not know how to use this application. The level of the statement of respondents is very high on the problem of access into the Schoology application.

\section{Question 5:}

What about the scope of material delivered by the lecturer during the outbreak?

Respondents in this study averaged that the learning objectives provided by the lecturers could be understood by them. Similarly, with the material compiled by lecturers, the majority of respondents stated that it was quite good. Regarding the ability of students to participate in studying this subject, respondents stated that it was quite good. However, the majority of students noted that the density of material was so large that they faced obstacles in completing some of the quizzes given by the lecturers who are influential in this course. The following table shows the responses of students who were respondents in this study.

The flexibility of online learning in terms of material and the process of providing material can be a major advantage compared to face to face learning methods. A positive thing that can be learned from a pandemic is the possibility of opening access to learning for all parties, especially students who are out of reach of learning because of limited funding [14]. The COVID-19 pandemic, which was followed by a temporary halt in teaching and learning activities, opened the view of policymakers in the education sector in each country that the learning process in the emergency period needed to be prepared. Teachers need to be trained to use online learning both with predetermined platforms or applications in Android and Apple Apps. For example, teachers in the Philippines use social media to communicate with students during the COVID-19 pandemic [15].

\section{Question 6:}

How about the performance of lecturer on elearning during the outbreak?

Based on the results of distributing questionnaires online, most of the students who were respondents in this study stated that lecturers who took Operational Research courses using Schoology application media on average could teach lecture material effectively. They also generally stated that the lecturer made a video presentation that was clear enough and organized so that students could playback the video if they had difficulties. According to the respondents, the lecturers also keep motivating students to carry out online learning during a pandemic even though it is realized that the lecturers face obstacles to prepare teaching materials that are easily understood by students while students face difficulties in accessing videos online. This thing done by the lecturer aims to increase the enthusiasm of students in conducting the online learning process. Respondents in this study generally also stated that to reduce the difficulty of students in understanding the material, the lecturer gave the opportunity for students to make feedback through the WhatsApp group. This media can help students in asking if they have difficulties in learning during the pandemic. The following table can clarify the extent of the performance of lecturers in Operations Research during online learning during the COVID19 pandemic.

The issue of quality online learning is a major issue in dealing with the COVID-19 pandemic. During the period of social restrictions, students face external and internal obstacles that can increase their dissatisfaction. Some reasons that prevent them from participating in online learning include a slow and hard-to-reach internet connection. This situation also occurs in countries such as the Philippines, where students have difficulty getting internet access while studying during the COVID-19 pandemic [15]. Therefore, teaching staff must also actively add information through social media such as WhatsApp or media messenger or via Instagram telegram and other social media applications. The reason, many students use social media as a bridge to get additional information in the form of questions when they cannot understand the material presented in an interface via online or through video. In addition to the negative impacts or obstacles that are still faced by students and lecturers, this online learning benefits students to be more flexible in managing study time, and in saving on transportation costs. 


\section{CONCLUSION}

During this time or before the COVID-19 pandemic, students are accustomed to face-to-face teaching patterns in class so that there are still many students who face difficulties in using online learning applications, especially the Schoology application. Internet access is the main issue for the students to learn during the outbreak. The load of assignment is also the main issue as well as the difficulty to apply group assignment. Thus, these issues should be evaluated by lecturer so that those could be overcome and sustain students' motivation in the study. When viewed from the pattern of student behaviour during a pandemic, students on average open an online learning application more than ten times a day. This fact shows that students' motivation to learn continues to increase even though they do not meet directly with their lecturers. Adequate internet access is one of the important issues that must be prepared in the future when facing an emergency. Internet access enables students to continue learning activities from home to avoid spreading the virus. The ability of lecturers to prepare material needed by students and additional material in the form of learning videos is very useful in increasing student motivation in learning the material provided.

\section{REFERENCES}

[1] C. Huang, Y. Wang, X. Li, L. Ren, J. Zhao, Y. Hu, L. Zhang, G. Fan, J. Xu, X. Gu, Z. Cheng, T. Yu, J. Xia, Y. Wei, W. Wu, X. Xie, W. Yin, H. Li, M. Liu and B. Cao, "Clinical feature of patients infected with 2019 novel coronavirus in Wuhan," The Lancet, vol. 395, no. 10223, pp. 497-506, 2020.

[2] J. Guarner, "Three emerging coronaviruses in two decades: The story of SARS, MERS, and now COVID-19," American Journal of Clinical Pathology, vol. 153, no. 4, pp. 420421, 2020.

[3] W. Preiser, G. Van Zyl and A. Dramowski, "COVID-19: Getting ahead of the epidemic curve by early implementation of social distancing," South African Medical Journal, vol. OnlineFirst, no. 1, 2020.

[4] I. Allen and J. Seaman, "Learning on demand: Online education in the United States,"
Babson Survey Research Group (Original work published 2019), 2010.

[5] O. Faye, P. Boelle, E. Heleze, O. Faye, C. Loucoubar, N. Magassouba, B. Soropogui, S. Keita, T. Gakou, H. Bah el, L. Koivogui, A. Sall and S. Cauchemez, "Chain of transmission and control of Ebola virus disease in Conakry, Guinea, in 2014:An observational study," The Lancet, vol. 15, no. 3, pp. 320-326, 2015.

[6] E. Baloran, "Knowledge, Attitude, Anxiety and Coping Strategies of Students during COVID-19 Pandemic," Journal of Loss and Trauma, 2020.

[7] D. Roy, S. Tripathy, S. Kar, N. Sharma, S Verna and V. Kaushal, "Study of knowledge, attitude, anxiety \& perceived mental healthcare need in Indian population during COVID-19 Pandemic," Asian Journal of Psychiatry, vol. 51, pp. 102083-102087, 2020.

[8] J. Lee, "Mental health effects of school closures during COVID-19," The Lancet. Advance online publication, 2020.

[9] J. Bowen, Teaching naked: How moving technology out of your college classroom will improve student learning, Jossey-Bass, 2012.

[10] J. Rivera and M. Rice, "A comparison of student outcome \& satisfaction between traditional \& Web based course offering," Online Journal of Distance Learning Administration, vol. 5, no. 3, 2002.

[11] D. Carr, "Education, profession and culture: Some conceptual questions," British Journal of Educational Studies, vol. 48, no. 3, pp. 248 268, 2002.

[12] A. Jankowicz, "Business research project," Thomson Learning, 2000.

[13] D. Lederman, Preparing for a fall without inperson classes, Inside Higher Ed.

[14] M. P. A. Murphy, "COVID-19 and emergency eLearning Consequences of the securitization of higher education for post-pandemic pedadogy," Contemporary Security Policy, vol. 41, no. 3, pp. 492-505, 2020.

[15] K. Talidong and C. Toquero, "Philippine teachers' practices to deal with anxiety amid COVID-19," Journal of Loss and Trauma. Advance online publication, 2020. 